\title{
SISTEM PAKAR DIAGNOSIS KERUSAKAN MESIN FOTOCOPY MINOLTA CS PRO EP5000 DENGAN MENGGUNAKAN METODE FORDWARD CHAINING
}

\author{
${ }^{1} Y u s f i k a$ Yuliana \\ Program Studi Sistem Informasi, Fakultas Teknik dan Ilmu Komputer \\ Universitas Islam Indragiri (UNISI) \\ Jl. Provinsi No. 01 Tembilahan Hulu, Indragiri Hilir, Riau - Indonesia \\ Email:yusfikay@yahoo.com
}

\begin{abstract}
Mesin Fotocopy mempunyai peranan sangat penting dalam kebutuhan administrasi bagi setiap individu, sehingga pada masa sekarang segala sesuatu yang berhubungan dengan administrasi akan memerlukan mesin fotocopy untuk melakukan penggandaan dokumen. Penulisan skripsi ini membahas mengenai pembuatan suatu aplikasi yang dapat digunakan oleh pemakai mesin fotocopy Minolta CS PRO EP5000 dalam memecahkan masalah yang mungkin terjadi selama mesin fotocopy melakukan penggandaan, seperti masalah Drive Motor Utama Tidak Berfungsi (C0000), Tegangan Tinggi (C0200), Laci Kertas A4 Bermasalah (Cog20), Laci Kertas F4 Bermasalah (C0910), Toner bermasalah (C0070), Hasil Fotocopy Hitam (C0600). Pembuatan aplikasi ini menggunakan Visual Basic Studio (VB Net) dan database MySQL sebagai perangkat lunak. Metode penelitian yang digunakan yaitu metode observasi lapangan dengan cara melakukan wawancara langsung kepada pengguna mesin Fotocopy Minolta CS PRO EP5000 untuk mendapatkan informasi mengenai masalah yang ditimbulkan oleh mesin tersebut. Pengujian aplikasi dilakukan dengan cara menyebarkan kuesioner untuk mengetahui tingkat kepuasaan pengguna terhadap aplikasi. Sehingga disimpulkan bahwa aplikasi ini memudahkan dan membantu pengguna dalam menyelesaikan masalah yang timbul oleh mesin Fotocopy Minolta CS PRO EP5000.
\end{abstract}

Kata Kunci: Minolta CS PRO EP5000, Fordward Chaining, Visual Basic Studio, MySQL

\section{PENDAHULUAN}

Dengan melihat perkembangan dunia teknologi informasi pada saat ini yang terus berkembang, maka diharapkan dapat membantu para pengguna mesin Fotocopy tentang permasalahan yang terjadi dan cara mengatasinya dengan sebuah system yang telah terkomputerisasi. Dengan adanya system pakar maka diharapkan permasalahan yang terjadi dan cara penanganan masalah pada Mesin Fotocopy Minolta CS PRO EP5000 dapat diketahui dengan segera sehingga dapat memudahkan para pengguna sebelum menyerahkan permasalahan tersebut kepada teknisi yang bersangkutan.

Adapun tujuan dari penelitian ini adalah untuk Membangun sebuah sistem yang dapat membantu para pengguna mesin fotocopy untuk mengetahui kerusakan apa yang terjadi berdasarkan kode yang dimunculkan pada mesin fotocopy Minolta CS PRO EP5000 serta cara menanganinya. Dengan adanya system ini maka dapat menuangkan pengetahuan seorang pakar tanpa harus menghubungi pakar tersebut.

Dengan adanya system ini maka diharapkan semua permasalahan dapat diketahui dan ditangani dengan cepat sehingga tidak mengganggu pekerjaan para pengguna mesin Fotocopy Minolta CS PRO EP5000

\section{DASAR TEORI}

Sistem pakar mencakup beberapa persoalan mendasar, antara lain apa yang dimaksud dengan keahlian, siapa yang disebut pakar, bagaimana keahlian dapat ditransfer dan bagaimana sistem bekerja. Pengetahuan dari suatu sistem pakar mungkin dapat direpresentasikan dalam sejumlah cara. Salah satu metode yang paling umum untuk merepresentasikan pengetahuan adalah dalam 
bentuk tipe aturan (rule) if..then (Jika..maka). Representasi pengetahuan merupakan metode yang digunakan untuk mengkodekan pengetahuan dalam sebuah sistem pakar.Representasi dimaksudkan untuk menangkap sifat- sifat penting masalah dan membuat informasi itu dapat diakses oleh prosedur pemecahan masalah (Kusrini, 2008).

Adapun karakteristik dari metode representasi pengetahuan adalah : (1) Harus bisa diprogram dengan bahasa pemrograman atau dengan shells dan hasilnya disimpan dalam memori. (2) Dirancang sedemikian sehingga isinya dapat digunakan untuk proses penalaran. (3) Model representasi pengetahuan merupakan sebuah struktur data yang dapat dimanipulasi oleh mesin inferensi dan pencarian untuk aktifitas pencocokan pola. Runut Maju (Fordward Chaining) merupakan proses perunutan yang dimulai dengan menampilkan kumpulan data atau fakta yang meyakinkan menuju konklusi akhir. Runut maju juga bisa disebut sebagai penalaran forward (forward reasoning) atau pencarian yang dimotori data (data driven search). Jadi dimulai dari premis-premis atau informasi masukkan (if) dahulu kemudian menuju konklusi atau derived information (then).

Mesin fotocopy menggunakan prinsip dari hukum Coulomb. Listrik Statis Teknologi mesin fotocopy berasal dari pemanfaatan adanya muatan listrik yang berbeda yang menyebabkan gaya tarik menarik. Di dalam mesin fotocopy terdapat plat logam yang dilapisi zat selenium yang merupakan sumber muatan positif, sedangkan sumber muatan negatif yang akan ditarik oleh muatan positif terdapat pada toner (tinta). Pada saat kertas bergerak dalam mesin fotocopy, selenium akan menarik toner sehingga toner mencitrakan (menimbulkan) gambar atau tulisan pada kertas. Pada mesin Fotocopy Minolta ada beberapa bagian - bagian penting yang harus diketahui agar dapat mengoperasikan mesin, yaitu Bagian Luar, Control Panel dan Basic Screen(MINOLTA, 1997). Bagian Luar (MINOLTA,1997). (1) Front Door yaitu pintu depan yang berfungsi untuk mereset mesin. (2) Control Panel yang berfungsi untuk mengoperasikan program yang ada pada mesin. (3) Original Width Scale yang berfungsi untuk mengukur kertas. (4) OriginalGlass yang berfungsi untuk meletakkan asli fotocopy. (5) RightCover yang berfungsi untuk menutup body mesin sekaligus sebagai tempat untuk penambahan option yang lain seperti ADF. (6) RightDoor yang berfungsi untuk melakukan pengcopyan secara timbale balik dengan kapasitas sedikit. (7) CounterCover berfungsi untuk mengetahui berapa banyak jumlah copyan yang telah dilakukan oleh mesin. (8) 2 nd Driver yang berfungsi untuk meletakkan kertas dengan ukuran F4. (9) 1 st Driver yang berfungsi untuk meletakkan kertas dengan ukuran A4.

\section{PERANCANGAN DAN IMPLEMENTASI}

Pada bab ini akan membahas mengenai analisa dan perancangan Sistem Pakar Diagnosis Kerusakan Mesin Fotocopy Minolta CS PRO EP5000. Sebelum merancang sistem apa yang akan dibangun pada sebuah aplikasi maka terlebih dahulu melakukan sebuah perancangan alur logika sistem yang akan digunakan seperti perancangan Contex Diagram, Data Flow Diagram dan Entity Relationship Diagram (ERD).

Contex Diagram merupakan sebuah diagram sederhana yang menggambarkan hubungan antara entitas luar dengan sistem. Contex Diagram dapat dilihat pada gambar 1 dibawah ini :

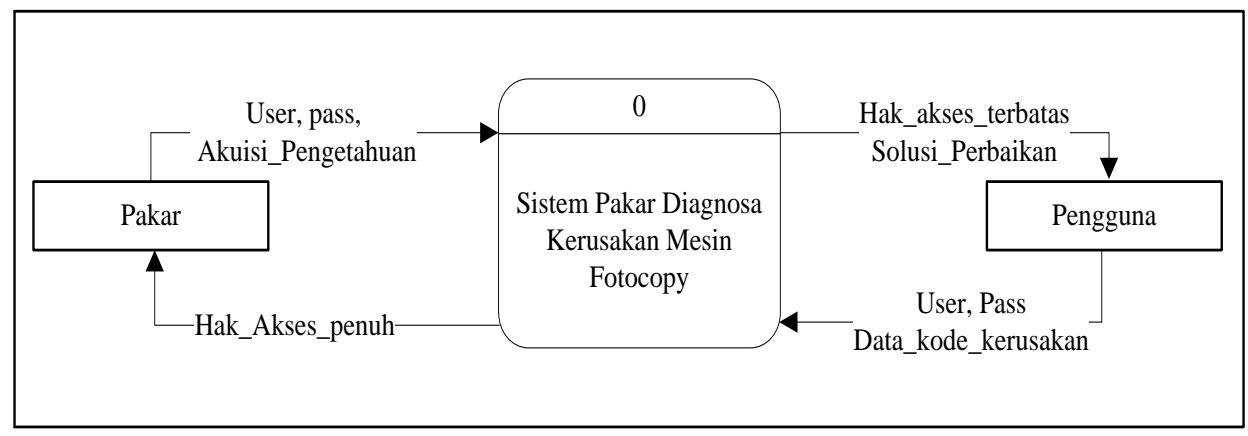

Gambar 1. Contex Diagram

Yuliana, Sistem Pakar Diagnosis Kerusakan Mesin Fotocopy Minolta Cs Pro Ep5000 Dengan Menggunakan Metode Fordward Chaining 
Data Flow Diagram merupakan suatu model logika data atau proses yang dibuat untuk menggambarkan dari mana asal data dan kemana tujuan data yang keluar dari sistem, dimana data disimpan, proses apa yang menghasilkan data tersebut dan interaksi antara data yang tersimpan dan proses yang dikenakan pada data tersebut.Data Flow Diagram dapat dilihat pada gambar 2 dibawah ini :

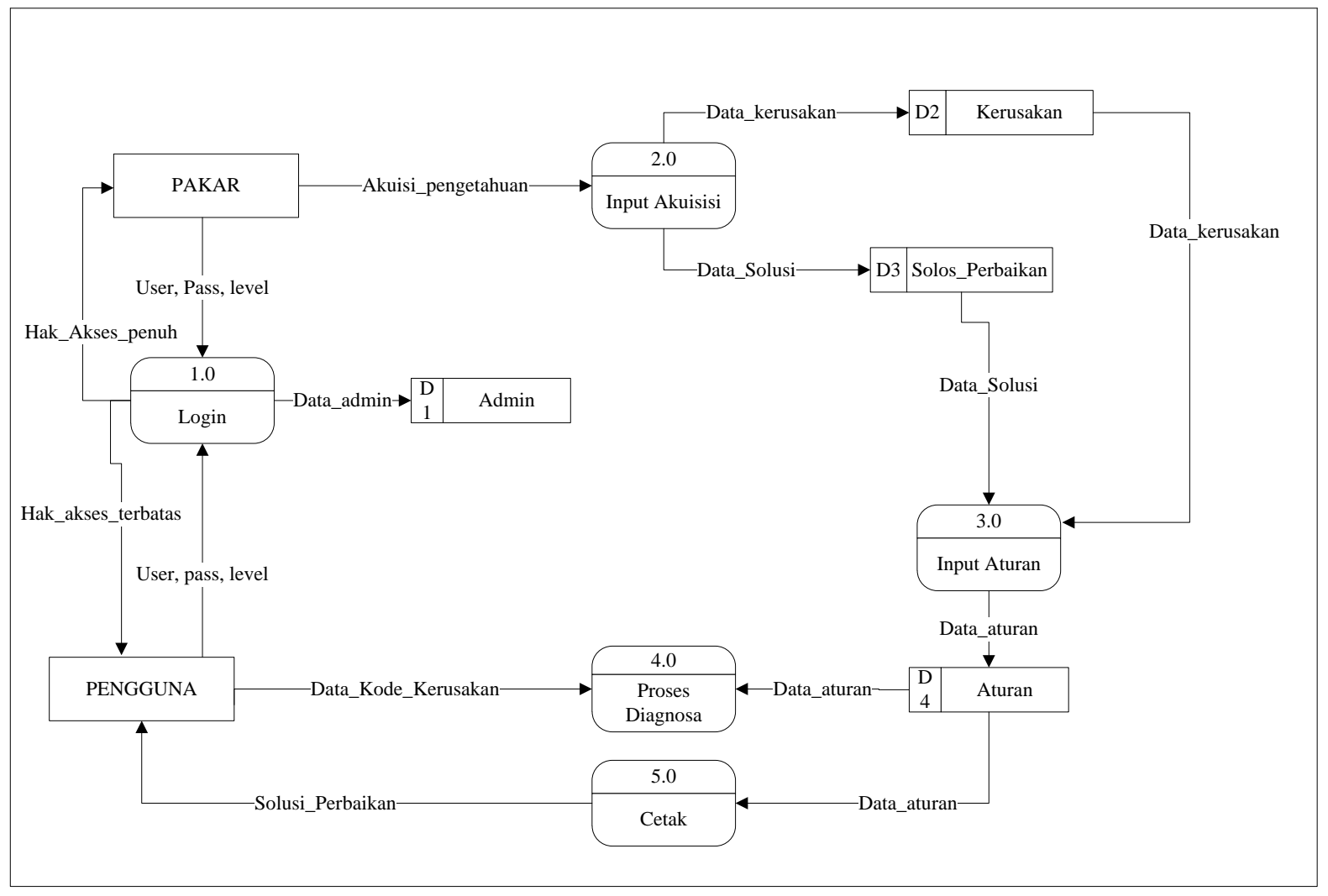

Gambar 2. Data Flow Diagram

Entity Relationship Diagram (ERD) adalah suatu model jaringan yang menggunakan susunan data yang disimpan dalam sistem secara abstrak.

\subsection{Analisa Sistem}

Sistem pakar adalah system berbasis komputer yang menggunakan pengetahuan, fakta dan teknik penalaran dalam memecahkan masalah. Untuk mengidentifikasi masalah perlu dilakukan analisa terhadap kinerja, informasi, ekonomi, pengendalian dan efisiensi terhadap pengguna. (1) Analisa terhadap kinerja yaitu penggunaan atau pengoperasian untuk sistem pakar ini tidaklah sulit, sistem ini dapat dengan mudah digunakan oleh siapa saja, engan menggunakan sistem ini maka akan mempermudah kinerja seorang mekanik dalam mengidentikasi jenis kerusakan. (2) Analisa Informasi yaitu dengan adanya sistem ini dapat mempermudah para pengguna untuk memperoleh informasi yang dibutuhkan dengan mengoperasikan sistem. (3) Analisa Ekonomi yaitu dengan adanya sistem ini diharapkan dapat meringankan biaya pengeluaran pengguna untuk melakukan proses konsultasi terhadap teknisi. (4) Analisa Pengendalian yaitu pembuatan system untuk melindungi pengguna dengan cara membuat username dan password. (5) Analisa Efisiensi yaitu dengan sistem pakar diagnosa kerusakan mesin fotocopy ini dapat mempermudah dan juga dapat mengefisienkan waktu serta tenaga para pengguna. 


\subsection{Perancangan Sistem}

Perancangan database merupakan sebuah perancangan yang dirancang untuk mengelola data dan menyimpan data dari masing- masing file yang nantinya akan diproses pada pengolahan data sistem tersebut.

Dalam aplikasi system pakar ini ada 2 buah perancangan antar muka yaitu antar muka login dan antar muka menu utama. Dimana pada antar muka login ini merupakan tampilan saat akan masuk kedalam aplikasi sedangkan antarmuka menu utama berisi tampilan awal pada saat masuk kedalam sistem. Gambar dapat dilihat pada gambar 3 dan gambar 4.

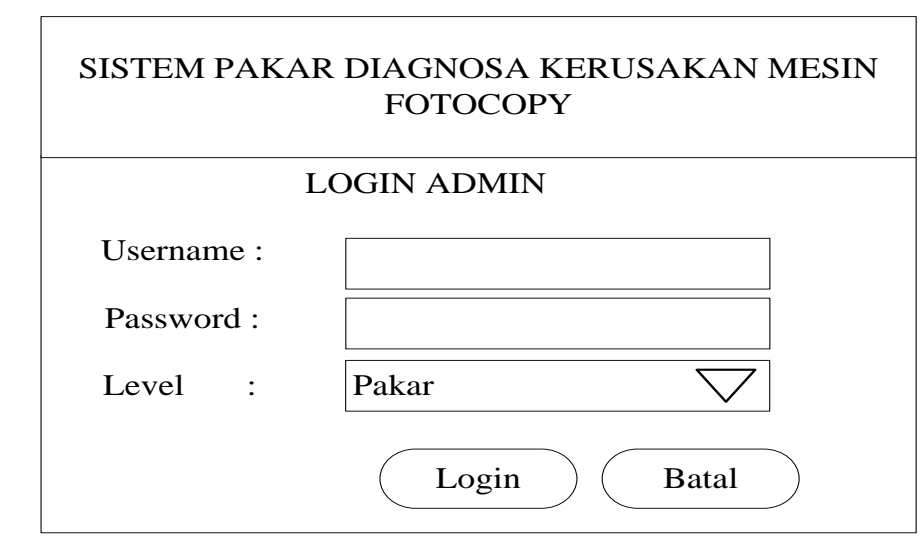

Gambar 3. Antarmuka Login

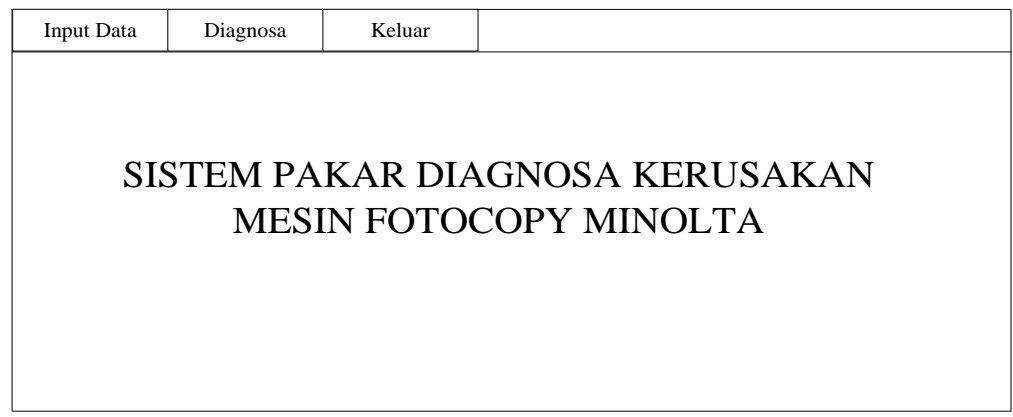

\section{Gambar 4. Antarmuka Menu Utama}

Perancangan input merupakan antarmuka yang digunakan oleh user untuk menginputkan data. Dalam aplikasi ini yang merupakan bagian dari input adalah input jenis kerusakan dan input solusi perbaikan sebagaimana tabel 1 dan tabel 2.

Tabel 1. Jenis Kerusakan

\begin{tabular}{|l|l|}
\hline No & Aturan Jenis kerusakan \\
\hline 1 & $\begin{array}{l}\text { IF Coooo } \\
\text { THENDrive Motor Utama tidak berfungsi }\end{array}$ \\
\hline 2 & $\begin{array}{l}\text { IF C0200 } \\
\text { THENMasalah Tegangan Tinggi }\end{array}$ \\
\hline 3 & $\begin{array}{l}\text { IF Co920, IF Co910 } \\
\text { THENLaci Kertas bermasalah. ( Co920 untuk kertas A4, } \\
\text { Co910 untuk kertas F4) }\end{array}$ \\
\hline 4 & $\begin{array}{l}\text { IF Co070 } \\
\text { THENToner bermasalah }\end{array}$ \\
\hline 5 & $\begin{array}{l}\text { IF CO600 } \\
\text { THENHasil Fotocopy Hitam }\end{array}$ \\
\hline
\end{tabular}


Tabel 2. Solusi Perbaikan

\begin{tabular}{|c|c|}
\hline No & uran Jenis Kerusakan \\
\hline 1 & $\begin{array}{l}\text { Disebabkan karena Drive Motor Utama tidak bergerak atau mati total, oleh } \\
\text { karena itu periksa bagian Fusing Unit.Cek apakah Fusing Unit berputar } \\
\text { dengan baik, keras atau lunak dengan cara keluarkan fusing unit dari mesin. } \\
\text { periksa apakah bering-bering pada Fusing Unit macet atau tidak berputar. } \\
\text { Jika macet maka gunakan minyak pelumas seperti minyak singer AND Cek } \\
\text { Bagian Developing Unit. Caranya keluarkan bagian Developing dari mesin. } \\
\text { Pastikan gear-gear pada bagian developing unit tidak ada yang patah atau } \\
\text { aus, lihat gambar. Jika patah atau sudah aus maka ganti dengan gear yang } \\
\text { baru. } \\
\text { IF Drive Motor Utama tidak berfungsi }\end{array}$ \\
\hline 2 & $\begin{array}{l}\text { Disebabkan karena arus listrik. Oleh karena itu apabila menggunakan mesin } \\
\text { fotocopy harap menggunakan stavol untuk mengatur arus listrik. Stavol } \\
\text { yang digunakan minimal yang berukuran } 3 \text { kilo sampai } 5 \text { kilo AND matikan } \\
\text { mesin fotocopy tunggu beberapa saat lalu hidupkan kembali. } \\
\text { IF Tegangan Tinggi }\end{array}$ \\
\hline 3 & $\begin{array}{l}\text { Disebabkan karena laci kertas kotor. Oleh karena itu keluarkan laci kertas } \\
\text { dari mesin fotocopy. Kemudian bersihkan bagian dalam laci dengan } \\
\text { menggunakan kuas sehingga debu-debu atau sampah yang ada } \\
\text { didalamnya hilang. } \\
\text { IF Laci Kertas bermasalah }\end{array}$ \\
\hline 4 & $\begin{array}{l}\text { Disebabkan karena kehabisan tinta. Oleh karena itu isi kembali tinta dengan } \\
\text { cara keluarkan tabung tinta yang ada pada mesin. Langkah pertama buka } \\
\text { pintu bagian depan mesin seperti pada gambar, Kemudian tarik keluar } \\
\text { tabung tinta. Setelah tabung tinta keluar maka isi tinta dengan } \\
\text { menuangkan serbuk tinta pada lubang tabung, lalu masukkan kembali } \\
\text { tabung tinta kedalam mesin dengan cara mendorong. } \\
\text { IFToner bermasalah }\end{array}$ \\
\hline 5 & $\begin{array}{l}\text { Disebabkan oleh kaca kotor, scanner pada mesin kotor dan pengaturan } \\
\text { pencahayaan pada mesin. Oleh karena itu bersihkan bagian kaca mesin } \\
\text { fotocopy dengan kain yang lembut. Setelah dibersihkan buka kaca tersebut } \\
\text { untuk membersihkan bagian scanner yang terdapat dibawah kaca dengan } \\
\text { cara membuka baut yang ada disamping kiri lalu angkat kaca keluar dari } \\
\text { mesin. } \\
\text { Setelah bagian kaca terbuka maka bersihkan bagian scanner yang ada } \\
\text { didalam dengan kain yang lembut } \\
\text { Setelah dibersihkan tutup kembali kaca seperti semula. AND periksa } \\
\text { pengaturan pencahayaan pada mesin dengan cara pilih menu, lalu pilih } \\
\text { basic lalu pilih Auto Expo. Lalu akan muncul gambar maka pilih Lihgter } \\
\text { IF Hasil Fotocopy Hitam }\end{array}$ \\
\hline
\end{tabular}

Perancangan output adalah suatu perancangan yang memuat informasi kepada para pengguna. Dalam sistem ini yang merupakan perancangan output yaitu berupa hasil dari analisa kerusakan. 


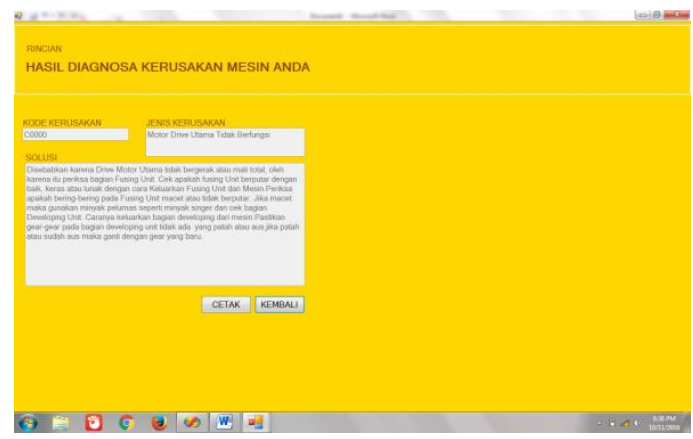

\section{Gambar 5. Form Tampilan Output (Solusi Perbaikan)}

Laporan merupakan hasil akhir dari sebuah sistem. Dimana laporan tersebut berfungsi sebagai bahan acuan yang akan digunakan oleh pengguna dalam tahap akhir penggunaan sistem. Laporan dalam sistem ini berupa print out hasil dari analisa kerusakan dan cara penanganannya.

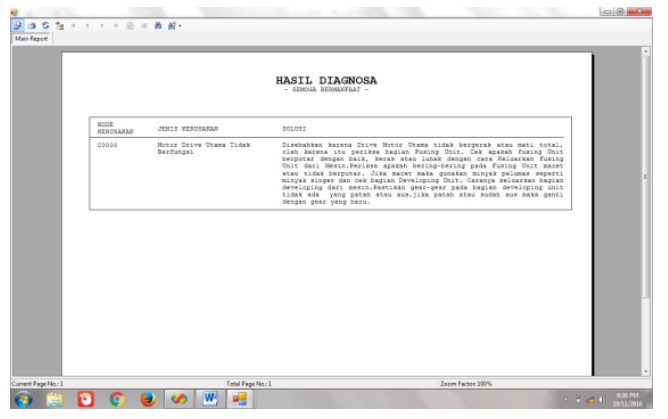

\section{Gambar 6. Form Tampilan Output (Solusi Perbaikan)}

\section{PEMBAHASAN}

\subsection{Pengujian Kebenaran Sistem}

Tahap Implementasi merupakan tahap dimana sistem yang telah dianalisa dan dirancang sebelumnya akan diterapkan, baik itu berupa perangkat lunak maupun perangkat keras yang digunakan.

Implementasi program merupakan cara yang dilakukan untuk menjalankan sistem yang telah dirancang.

Pada aplikasi diagnosis kerusakan mesin fotocopy ini ada dua akses yang disediakan, yaitu akses admin yang memiliki akses penuh dan akses pengguna yang memiliki akses terbatas. Dapat dilihat pada gambar 7 .

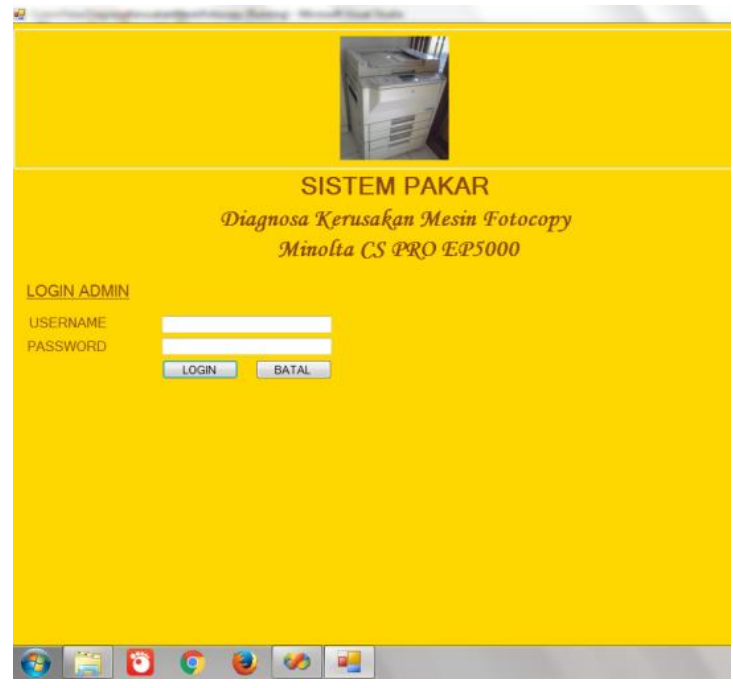

\section{Gambar 7. Form Login}


Form Menu Utama ini merupakan tampilan awal saat user masuk kedalam aplikasi. Pada tampilan ini user bisa memilih berbagai menu pilihan untuk menggunakan aplikasi lebih rinci lagi. Dapat dilihat pada Gambar 8.

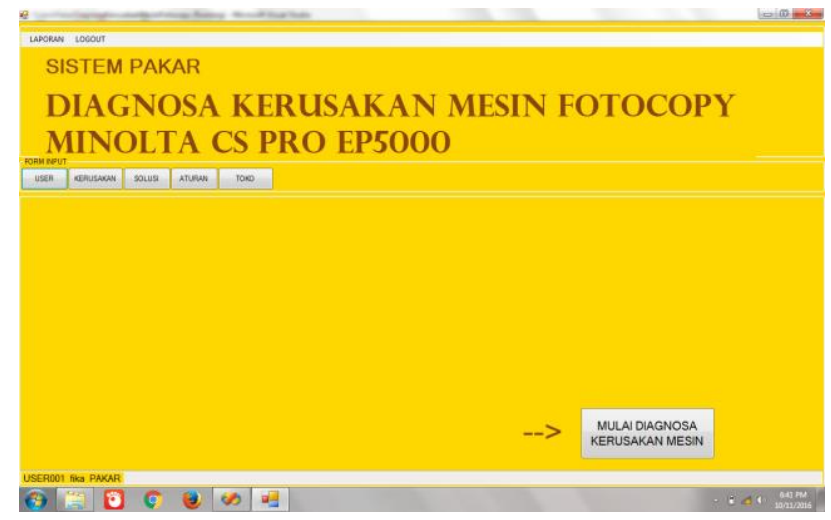

Gambar 8. Form Menu Utama

Pada form ini admin dapat memasukkan data toko yang akan menggunakan aplilasi sehingga toko tersebut mendapatkan kode akses.

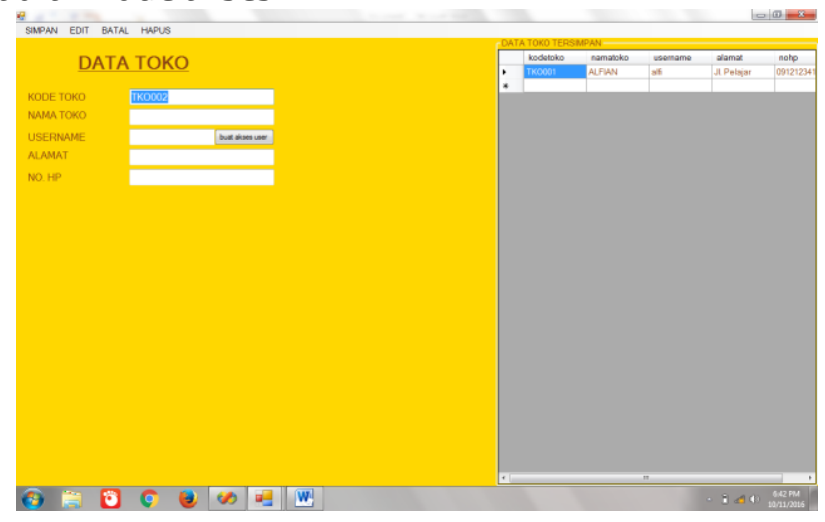

Gambar 9. Form Input Data Toko

Pada gambar ini merupakan gambar tampilan untuk menginputkan data toko yang akan menggunakan aplikasi tersebut. Tampilan form berikut merupakan tampilan dari permasalahan kode yang ditimbulkan oleh mesin.

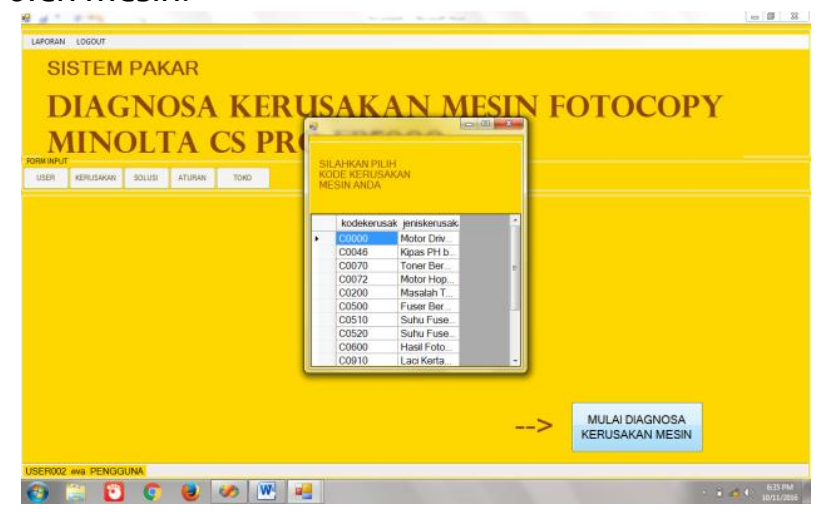

Gambar 10. Tampilan Kode Kerusakan Mesin

Tampilan form berikut merupakan pemecahan masalah dari kode yang ditimbulkan 


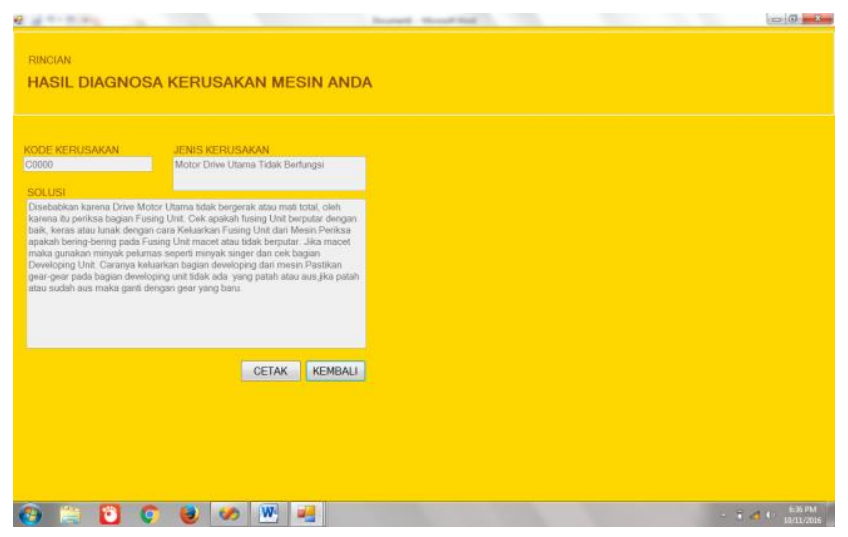

Gambar 11. Tampilan Masalah

Tampilan report berikut merupakan Hasil dari diagnose berdasarkan kode yang ditimbulkan.

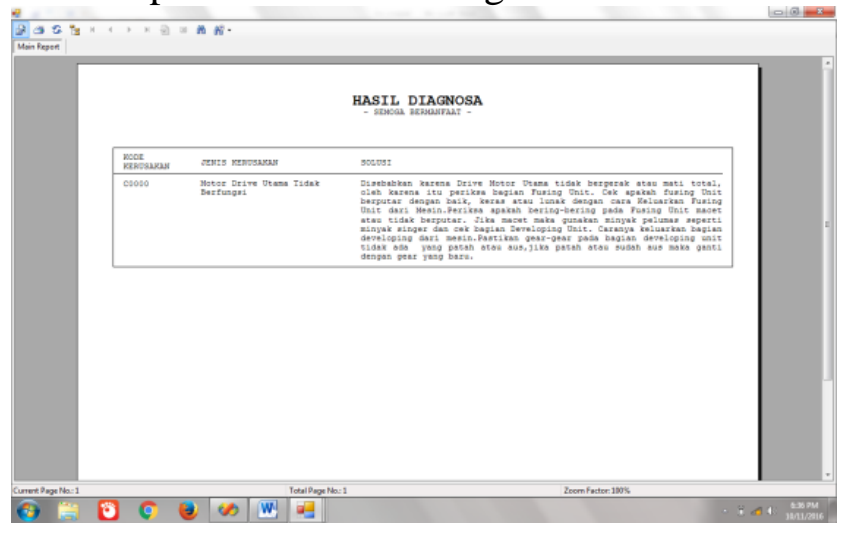

Gambar 12. Report Hasil Diagnosa

\subsection{Pengujian Sistem}

Pengujian system menggunakan black box dan white box. Dimana pengujian black box yaitu pengujian yang dilakukan hanya mengamati hasil eksekusi melalui data uji dan memeriksa fungsional dari perangkat lunak, sedangkan pengujian white box yaitu pengujian yang didasarkan pada pengecekan terhadap detail perancangan, menggunakan struktur kontrol dari desain program secara procedural untuk membagi pengujian ke dalam beberapa kasus pengujian.

\subsection{Pengujian Kelayakan Sistem}

Setelah membangun sebuah aplikasi maka diperlukan untuk menguji kelayan system tersebut. Dimana untuk pengujian system ini penulis memilih dengan menggunakan penyebaran quesioner kepada para pengguna mesin Fotocopy Minolta CS Pro EP5000 yang ada di Kota Tembilahan. Quesioner yang disebarkan sebanyak 10 responden. Untuk menghitung seberapa layak system yang telah dibuat maka penulis menggunakan metode perhitungan Skala Likert dalam perhitungan persentase kelayakan. Dari hasil 10 responden tersebut maka dapat diketahui hasil akhir persentase kelayakan system sebagai mana tabel 3 berikut :

Tabel 3. Hasil Uji Kelayakan Sistem

\begin{tabular}{|c|c|c|c|c|c|c|c|}
\hline \multirow[t]{2}{*}{ No } & \multirow{2}{*}{$\begin{array}{l}\text { Kriteria } \\
\text { Penilaian }\end{array}$} & \multicolumn{5}{|c|}{ Frekuensi Jawaban } & \multirow[t]{2}{*}{ Persentase } \\
\hline & & SS & $\mathrm{S}$ & $\mathrm{N}$ & TS & TSS & \\
\hline 1 & Mudah Digunakan & 4 & 5 & 1 & & & $82 \%$ \\
\hline 2 & Mudah Untuk Dipelajari & 5 & 5 & & & & $90 \%$ \\
\hline 3 & Desain Yang Menarik & & 2 & 5 & 3 & & $72,5 \%$ \\
\hline 4 & Dapat Membantu & 8 & 2 & & & & $96 \%$ \\
\hline
\end{tabular}




$$
\begin{aligned}
& \text { Keterangan Tabel : } \\
& \begin{array}{ll}
\text { SS } & =\text { Sangat Setuju } \\
\text { S } & =\text { Setuju } \\
\text { N } & =\text { Netral } \\
\text { TS } & =\text { Tidak Setuju } \\
\text { TSS } & =\text { Tidak Sangat Setuju }
\end{array}
\end{aligned}
$$

\section{KESIMPULAN}

Berdasarkan penelitian yang telah dilakukan di Toko Fotocopy dapat diambil suatu kesimpulan bahwa dengan adanya sistem pakar diagnosis kerusakan mesin fotocopy Minolta ini maka dapat membantu para pengguna dalam menyelesaikan masalah mereka dengan cepat tanpa harus menunggu penanganan dari teknisi atau mencari ilmu lain seperti buku. Sehingga dapat membantu dalam proses pekerjaan mereka.

\section{REFERENSI}

Arhami Muhammad. Konsep Dasar Sistem Pakar. Yogyakarta : Andi. 2004

Andri dan Kusrini. Membangun Sistem Informasi Akuntansi dengan Visual Basic \& Microsoft SQL

Server. Yogyakarta : Andi. 2009.

Kristanto, Andri. Perancangan Sistem Informasi dan Aplikasinya. Yogyakarta : Grava Media. 2007.

Kusrini. Aplikasi Sistem Pakar. Yogyakarta : CV. Andi Offset. 2008

Kusrini. Sistem Pakar Teori dan Aplikasinya. Yogyakarta : Andi Offset. 2006.

Kustiyahningsih, Yeni dan Anamisa, D.R. Pemrograman Basis Data Berbasis Web menggunakan PHP \& MySQL. Graha Ilmu. 2010.

Ladjamuddin, Al- Bahra. Analisa dan Desain Sistem Informasi. Yogyakarta : Graha Ilmu. 2005.

Hartati Sri, Iswanti Sari. Sistem Pakar dan Pengembangannya. Yogyakarta : Graha Ilmu. 2008

T. Sutojo dkk. Kecerdasan Buatan. Yogyakarta: Andi. 2011.

Turban, Efraim dkk. Decision Support System and Intellegent System. Yogyakarta: Andi. 2005. 